\title{
Medical hypothesis: can gonadotropins influence thyroid volume in women with PCOS?
}

\author{
Evrim Cakir ${ }^{{ }^{*}}$, Mustafa Sahin ${ }^{2}$, Erman Cakal ${ }^{3}$, Mustafa Ozbek $^{3}$ and Tuncay Delibasi ${ }^{3}$
}

\begin{abstract}
It has been reported that luteinizing hormone $(\mathrm{LH})$ had thyropropic effect on rat and human thyroid membrane. It has been known that patients with PCOS have elevated LH levels in comparison to healthy controls.

The goiter prevalence is more common in women than in men regardless of population. The higher incidence of thyroid diseases in women has been previously attributed to higher estradiol levels. Estradiol has been shown to enhance proliferative and mitogenic activities of thyroid cells. However, in recent years chronic estradiol treatment has been shown to reduce volume densities of thyroid follicles, follicular epithelium and thyroid gland volume. It is thought to be due to LH suppression.

Therefore we suggested that increased LH levels might provide a stimulus for growth on thyroid and alter thyroid function. Therefore patients with PCOS who had elevated LH levels should be treated by combined estradiol pills such as estrogen-progestin contraceptives for suppression of LH secretion. Further studies are needed to evaluate the association between LH, LH suppression and thyroid volume in patients with PCOS.
\end{abstract}

Keywords: Thyroid volume, Luteinizing hormone, Polycystic ovary syndrome

\section{Background}

Human chorionic gonadotropin (hCG) secreting placental tumors such as hydatidiform moles and choriocarcinomas have been found to be associated with hyperthyroidism [1] and HCG has been reported to increase TSH receptor expression, thyroid hormone secretion, iodide uptake, organification, adenylate cyclase, and deoxribonucleic acid synthesis in rat and also cultured human thyrocytes [2-4].

Luteinizing hormone is a glycoprotein hormone like TSH and has similar alpha subunit. In Carayon et al. study LH has been identified to increase thyroid adenylate cylase activity 65 times more potently than HCG in human thyroid membranes [5]. Also, in Yoshimura et al. study human LH has been found to be more potent than HCG in binding to the TSH receptor and stimulating adenylate cyclase [6]. As mentioned above, hCG and LH have thyrotropic effect on rat and human thyroid membrane.

\footnotetext{
* Correspondence: drevrimcakir@gmail.com

'Department of Endocrinology and Metabolic Diseases, Amasya

Sabuncuoglu Serefettin Hospital, Amasya, Turkey

Full list of author information is available at the end of the article
}

Our hypotheses is increased LH levels might have a growth effect on thyroid gland in patients with polycystic ovary syndrome (PCOS). Polycystic ovary syndrome is a common endocrine disorder affecting at least five to $10 \%$ of women of reproductive age [7].

The goiter prevalence is more common in women than in men regardless of population [8]. However, there have been no data on increased thyroid volume or goitre prevalence in women with PCOS versus women with regular menstrual cycles. The higher incidence of thyroid diseases in women has been previously attributed to higher estradiol levels. Estradiol has been shown to enhance proliferative and mitogenic activities of thyroid cells $[9,10]$. However, in recent years chronic estradiol treatment has been shown to reduce volume densities of thyroid follicles, follicular epithelium and thyroid gland volume $[11,12]$. Despite the enhancing effect of estradiol on thyroid cells, the reducing effect of chronic estradiol treatment on thyroid volume can be related to $\mathrm{LH}$ suppression.

It has been known that patients with PCOS have elevated LH levels [13,14] and also have higher gonadotrophin-releasing hormone (GnRH)-stimulated LH concentrations in comparison to healthy controls 
[15]. In relation to present hypotheses in Knudsen et al. study 3712 women were evaluated and found that oral contraceptives were related with a lower thyroid volume and reduced risk of goiter. In this study the oral contraceptives users had goitre four times less common than non-users [12]. In this case, the LH suppression with oral contraceptives including estradiol might be the factor for decreased thyroid volumes consistent with present hypotheses. However, this literature applies to general population of women, and not to women with PCOS and additionally, in literature search there is no data that the use oral contraceptives in women with PCOS is associated with reduction of thyroid volume or lower goitre prevalence.

In the recent hypotheses increased LH levels might provide a stimulus for growth on thyroid and alter thyroid function. Therefore patients with PCOS who had elevated LH levels should be treated by combined estradiol pills such as estrogen-progestin contraceptives for suppression of LH secretion. Further studies are needed to evaluate the association between $\mathrm{LH}, \mathrm{LH}$ suppression and thyroid volume in patients with PCOS.

\footnotetext{
Author details

${ }^{1}$ Department of Endocrinology and Metabolic Diseases, Amasya Sabuncuoglu Serefettin Hospital, Amasya, Turkey. ${ }^{2}$ Department of Endocrinology and Metabolic Diseases, Ankara University Hospital, Ankara, Turkey. ${ }^{3}$ Department of Endocrinology and Metabolic Diseases, Diskapi Yildirim Beyazit Training and Research Hospital, Ankara, Turkey.
}

Received: 9 October 2012 Accepted: 27 November 2012 Published: 29 November 2012

\section{References}

1. Yoshimura M, Hershman JM: Thyrotropic action of human chorionic gonadotropin. Thyroid 1995, 5(5):425-434.

2. Hershman JM: Role of human chorionic gonadotropin as a thyroid stimulator. J Clin Endocrinol Metab 1992, 74(2):258-259.

3. Hershman JM, Lee HY, Sugawara M, Mirell CJ, Pang XP, Yanagisawa M, Pekary AE: Human chorionic gonadotropin stimulates iodide uptake, adenylate cyclase, and deoxyribonucleic acid synthesis in cultured rat thyroid cells. J Clin Endocrinol Metab 1988, 67(1):74-79.

4. Kraiem Z, Sadeh O, Blithe DL, Nisula BC: Human chorionic gonadotropin stimulates thyroid hormone secretion, iodide uptake, organification, and adenosine 3',5'-monophosphate formation in cultured human thyrocytes. J Clin Endocrinol Metab 1994, 79(2):595-599.

5. Carayon P, Lefort G, Nisula B: Interaction of human chorionic gonadotropin and human luteinizing hormone with human thyroid membranes. Endocrinology 1980, 106(6):1907-1916.

6. Yoshimura M, Hershman JM, Pang XP, Berg L, Pekary AE: Activation of the thyrotropin (TSH) receptor by human chorionic gonadotropin and luteinizing hormone in Chinese hamster ovary cells expressing functional human TSH receptors. J Clin Endocrinol Metab 1993, 77(4):1009-1013

7. Norman RJ, Dewailly D, Legro RS, Hickey TE: Polycystic ovary syndrome. Lancet 2007, 370(9588):685-697.

8. Vanderpump MP, Tunbridge WM, French JM, Appleton D, Bates D, Clark F, Grimley Evans J, Hasan DM, Rodgers H, Tunbridge F, et al: The incidence of thyroid disorders in the community: a twenty-year follow-up of the Whickham Survey. Clin Endocrinol (Oxf) 1995, 43(1):55-68.

9. Rajoria S, Suriano R, Shanmugam A, Wilson YL, Schantz SP, Geliebter J, Tiwari RK: Metastatic phenotype is regulated by estrogen in thyroid cells. Thyroid 2010, 20(1):33-41.
10. Furlanetto TW, Nguyen $L Q$, Jameson JL: Estradiol increases proliferation and down-regulates the sodium/iodide symporter gene in FRTL-5 cells. Endocrinology 1999, 140(12):5705-5711.

11. Sosic-Jurjevic B, Filipovic B, Milosevic V, Nestorovic N, Manojlovic-Stojanoski $M$, Brkic B, Sekulic M: Chronic estradiol exposure modulates thyroid structure and decreases T4 and T3 serum levels in middle-aged female rats. Horm Res 2005, 63(1):48-54.

12. Knudsen N, Bulow I, Laurberg P, Perrild H, Ovesen L, Jorgensen T: Low goitre prevalence among users of oral contraceptives in a population sample of 3712 women. Clin Endocrinol (Oxf) 2002, 57(1):71-76.

13. Arroyo A, Laughlin GA, Morales AJ, Yen SS: Inappropriate gonadotropin secretion in polycystic ovary syndrome: influence of adiposity. J Clin Endocrinol Metab 1997, 82(11):3728-3733.

14. Taylor AE, McCourt B, Martin KA, Anderson EJ, Adams JM, Schoenfeld D, Hall JE: Determinants of abnormal gonadotropin secretion in clinically defined women with polycystic ovary syndrome. J Clin Endocrinol Metab 1997, 82(7):2248-2256.

15. Lewandowski KC, Cajdler-Luba A, Bienkiewicz M, Lewinski A: Women with oligo-/amenorrhoea and polycystic ovaries have identical responses to $\mathrm{GnRH}$ stimulation regardless of their androgen status: comparison of the Rotterdam and Androgen Excess Society diagnostic criteria. Neuro Endocrinol Lett 2011, 32(6):847-856.

doi:10.1186/1756-6614-5-17

Cite this article as: Cakir et al:: Medical hypothesis: can gonadotropins influence thyroid volume in women with PCOS?. Thyroid Research 2012 5:17.

\section{Submit your next manuscript to BioMed Central and take full advantage of:}

- Convenient online submission

- Thorough peer review

- No space constraints or color figure charges

- Immediate publication on acceptance

- Inclusion in PubMed, CAS, Scopus and Google Scholar

- Research which is freely available for redistribution 